\title{
Bipolar Affective Disorder In Adolescents
}

[R:

José Antonio de Lima Neto1, Pedro Henrique Gomes Sudário Lins', Carlos Magno Alencar Dias de Oliveira', Emerson Pier de Almeida', Francisco Ananias Mamede de Morais Junior', Leandro Eduardo Sena Oliveira ${ }^{1}$, Ricardo Oliveira Alexandre', Sonilde Saraiva Januárioº ${ }^{2}$, Edglê Pedro de Sousa Filho², Uilna Natércia Soares Feitosa², Maryldes Lucena Bezerra de Oliveira², Martha Maria Macedo Bezerra², Modesto Leite Rolim Neto ${ }^{1,2}$

\section{Abstract}

Bipolar disorder (BD) is a chronic condition characterized by mood swings that is not rarely presented in adolescents. The presence of comorbid disorders is believed to affect negatively the patient's state. It has been investigated predictors and risk factors for this disease and it might be a path to get more understanding about the psychopathology underneath the BD. The concomitant substance use disorders in a bipolar individual are a challenge to achieve a successful treatment. The diagnosis of $\mathrm{BD}$ is still not clearly stablished, as well as the most effective treatment is still controversial and undefined. Suicide in a depressive frame of bipolar disorder is one of the biggest concerns for the medicine field.

\section{Keywords}

Adolescents; Bipolar Affective Disorders; Treatment.

Bipolar disorder which is not uncommon in youth $[1,2]$ is often characterized by continuous, rapid-cycling, irritable, and mixed symptoms of depression and mania or hypomania. It may co-occur with disruptive behavior disorders, particularly attention deficit hyperactivity disorder (ADHD) or conduct disorder [1, 3].

Similar to adults with $\mathrm{BD}$, youth can be diagnosed with several subtypes of bipolar disorders including BD-I (periods of mania and major depression), BD-II (episodes of hypomania and major depression), Mixed episodes (symptoms of mania and depression occurring within the same 2-week time frame), cyclothymia (periods of hypomania and

1 Faculty of Medicine, Estácio -FMJ, Juazeiro do Norte, Ceará, Brazil.

2 Postgraduate Program in Health Sciences, FMABC, Santo André, São Paulo, Brazil.

Contact information:

Modesto Leite Rolim Neto.

$\equiv$ modestorolim@yahoo.com.br 
mild depressions), and BP-not otherwise specified (BP-NOS) [4, 5, 6, 7, 8, 9, 10, 11].

In early-onset bipolar disorder, the onset of symptoms occurs before 18 years of age [11, 12, 13, 14, 15]. These patients suffer long-term consequences that substantially impair their ability to perform normal func $\neg$ tions of daily life, consequently having devastating impact on their school performance, family relationships, and social interactions $[11,16]$.

The exact prevalence of pediatric bipolar disorder is unknown, but it is estimated that bipolar spectrum conditions may affect $2 \%$ of children and adolescents worldwide $[11,17,18]$. Half to two-thirds of patients with bipolar disorder have their first mood episode before age 18 [19-21], and pediatric bipolar disorder is highly recurrent [19].

The early signs that predict the continued course of adolescent mood disorders are not well established. Thus, we do not know which adolescents with a mood disorders will develop BD, major depressive disorder (MDD), or neither as adults [22]. Adolescent $\mathrm{BP}$ is associated with early signs such as mood lability or swings, anxiety, hyperarousal, somatic complaints, behavioral dysregulation, attention difficulties and school problems [22, 23, 24, 25, 26, 27, 28]. Disruptive behavioral disorders, in combination with mood changes, have been identified as more specific markers of the early onset of BPD [23, 29, $30,31,32,33]$. It has also been found that the presence of anxiety disorders, especially panic disorder, might be a marker as well [23, 34, 35, 36, 37].

Studies have described a number of correlates of comorbid substance use disorders (SUD) among adolescents with BP, including older age, panic disorder, oppositional defiant disorder/conduct disorder (ODD/CD), psychosis, family history of SUD, and previous alcohol experimentation [38, 39, 40, 41, 42]. The presence of comorbid SUD poses a substantial challenge in the treatment of patients with severe mental disorders $[43,44]$. Comorbid SUDs are associated with more severe psychotic and depressive symptoms [43, 45, 46], more frequent hospitalizations $[43,47]$, more involuntary hospitalization [43, 48], and poorer treatment response and outcome $[43,49,50]$. Most studies of comorbidity between severe mental disorders and SUD are based on data from surveys or clinical samples. Results from representative US population surveys have indicated that $30-50 \%$ of individuals with psychotic illness [43, 51, $52]$ or affective mood disorder $[43,53,54]$ have a comorbid alcohol use disorder (AUD) or non-alcohol drug use disorder (DUD). More recently, two smaller clinical studies from Scandinavian populations have reported similar results with prevalences of 20-30 $\%$ for SUD in schizophrenia $[43,55,56]$ and bipolar disorder [43, 50, 57].

Youth can be diagnosed with mania or hypomania using the existing Diagnostic and Statistical Manual of Mental Disorder (DSM) criteria for adults [58, 59, 60, 61, 62, 63, 64]. Diagnosis of Bipolar spectrum disorders (BPSD) in youth remains a difficult but important clinical responsibility. Assessment strategies are needed that are inexpensive, easy to implement, have good predictive power, and simultaneously combine multiple pieces of clinical information to increase or decrease the probability of BPSD $[65,66]$.

Research into the treatment of $\mathrm{BD}$ in children and adolescents has increased in recent years, especially regarding the use of Second-Generation Antipsychotics (SGAs). However, many uncertainties remain. Current algorithms suggest starting with monotherapy and then progressing to combination treatment with two different classes of drugs [67]. To control mood episodes and prevent relapse, these pediatric patients require careful treatment [10, 68]. Pharmacotherapeutic options for treating bipolar disorder in adolescents now also include several atypical antipsychotics [10, 69] with four medications currently approved for this population by the US Food and Drug Administration (FDA): aripiprazole, olanzapine, quetiapine, and risperidone. The emergence of atypical antipsychotics has provided 
treatments with fewer neurological side effects and greater tolerability $[10,70]$.

Although no specific SGA has proved to be more effective than others, available meta-analyses and comparative studies of RPCTs suggest that SGAs are more effective than traditional mood stabilizers. Furthermore, a head-to-head comparison of risperidone vs. lithium and divalproex showed that risperidone was superior in terms of efficacy, but with more metabolic side effects $[67,71]$.

Until recently, patients with bipolar disorder were rarely offered psychological therapies. The treatment of bipolar disorder is challenging as it does not only aim at resolving acute episodes, but also at preventing recurrences and assuring complete inter-episode recovery in terms of symptom remission and restoration of functioning. There is evidence from randomized, controlled trials that psychotherapy is an effective adjunct to medication in relapse prevention and episode stabilization among bipolar patients [72]. According to a recent meta-analysis, there is a significant reduction in relapse rate with adjunctive psychotherapy compared to standard treatment alone $[72,73]$. A recent systematic review concluded that as adjuncts to medication cognitive-behavioural therapy (CBT) and family-focused therapy (FFT) are efficacious with respect to the reduction of depressive symptoms, with interpersonal and social rhythm therapy (IPSRT) possibly efficacious $[72,74]$.

The ability to recognize facial emotional expressions is a fundamental skill that is necessary for successful social interaction and mood regulation. Borzorg et al. confirmed that adolescents with BD showed overall deficits in the accurate identification of emotions. The detection of emotion was significantly lower in the patient group compared to normal adolescents while they were viewing angry faces. This ability was also (nearly significant) lower while they needed to recognize sad and happy faces. Moreover, the time taken to detect emotional faces was longer in adolescents with BD compared to the normal developing adolescents. This process was particularly slower in identifying happy and neutral faces. These findings could be interpreted that youths with bipolar disorder have some problems in recognizing emotional faces in terms of accuracy and speed even when they are free from acute symptoms [1].

There are a few comorbid disorder associated with Bipolar Disorder. The scarce literature available suggests that Attention-deficit/hyperactivity Disorder (ADHD) and BD might share or promote synergistic neuropsychological deficits when comorbid. Children and adolescents presenting BD and comorbid ADHD show greater impairment in speed processing and interference control [75]. Also, there is conduct disorder (CD) comorbidity, the most important negative predictor of treatment nonresponse in BD children and adolescents [76, 77]. Youth with CD and $\mathrm{BD}$ presented higher rates of global aggression at the baseline, namely impulsive aggression, compared with those with either BD or CD alone, more frequent substance abuse, and poorer response to treatments [76, 78].

Patients with bipolar disorder have elevated mortality rates in comparison with the general population $[79,80]$. The excess mortality can be subdivided into deaths from avoidable causes and other deaths that are termed "unavoidable" $[79,81]$. Suicide is a leading cause of avoidable deaths in bipolar disorder. Comorbid alcohol and drug abuse must be identified and treated since it elevates the risk for suicide $[79,82]$. Lithium and anticonvulsant maintenance treatments have been the mainstays of suicide prevention in patients with major affective disorders $[79,83]$.The evidence supports the efficacy of cognitive behavioural therapy (CBT), in combination with pharmacological treatment for the prevention of relapse and of suicidal behavior $[79,84]$. 


\section{References}

1. Bozorg B, Tehrani-Doost M, Shahrivar Z, Fata L, Mohamadzadeh A. Facial Emotion Recognition in Adolescents with Bipolar Disorder. Iran J Psychiatry 2014; 9: 1: 20-24

2. Keller MB, Lavori PW, Mueller TI, Endicott J, Coryell W, Hirschfeld RM, et al. Time to recovery, chronicity, and levels of psychopathology in major depression. A 5-year prospective follow-up of 431 subjects. Arch Gen Psychiatry 1992; 49: 809816.

3. Carlson GA, Bromet EJ, Jandorf L. Conduct disorder and mania: what does it mean in adults. J Affect Disord. 1998; 48: 199-205.

4. Birmaher B. Bipolar disorder in children and adolescents. Child Adolesc Ment Health. 2013. 18(3).

5. Axelson D, Birmaher B, Strober M, Gill MK, Valeri S, Chiappetta L, Ryan N, Leonard H, Hunt J, lyengar S, Bridge J, Keller M. Phenomenology of children and adolescents with bipolar spectrumdisorders. Archives of general psychiatry. 2006; 63(10): 1139-1148.

6. Birmaher, B.; Axelson, D.; Pavaluri, M. Bipolar Disorder. In: Martin, M Andrés, MD; Volkmar, Fred R., MD; Lewis, Melvin, MB, BS, editors. Lewis' Child and Adolescent Psychiatry: A Comprehensive Textbook. 4th ed.. London: Lippincott Williams \& Wilkins (LWW); 2007.

7. Birmaher B, Williamson DE, Dahl RE, Axelson DA, Kaufman J, Dorn LD, Ryan ND, Birmaher B, Williamson DE, Dahl RE, Axelson DA, Kaufman J, Dorn LD, Ryan ND. Clinical presentation and course of depression in youth: does onset in childhood differ from onset in adolescence? Journal of Birmaher Page 11 Child Adolesc Ment Health. Author manuscript; available in PMC 2014 September 01. the American Academy of Child \& Adolescent Psychiatry. 2004; 43(1): 63-70.

8. DelBello MP, Hanseman D, Adler CM, Fleck DE, Strakowski SM. Twelve-month outcome of adolescents with bipolar disorder following first hospitalization for a manic or mixed episode. American Journal of Psychiatry. 2007; 164(4): 582-590.

9. Findling RL, Youngstrom EA, Fristad MA, Birmaher $B$, Kowatch RA, Arnold LE, Frazier TW, Axelson D, Ryan N, Demeter CA, Gill MK, Fields B, Depew J, Kennedy SM, Marsh L, Rowles BM, Horwitz SM. Characteristics of children with elevated symptoms of mania: the Longitudinal Assessment of Manic Symptoms (LAMS) study. The Journal of clinical psychiatry. 2010; 71(12): 1664-1672.

10. Youngstrom EA, Birmaher B, Findling RL. Pediatric bipolar disorder: validity, phenomenology, and recommendations for diagnosis. Bipolar Disorders. 2008; 10(1 Pt 2): 194-214.

11. Eiji Kirino. Profile of aripiprazole in the treatment of bipolar disorder in children and adolescents. Adolescent Health, Medicine and Therapeutics 2014: 5 211-221

12. Chang KD. The use of atypical antipsychotics in pediatric bipolar disorder. J Clin Psychiatry. 2008;69 Suppl 4: 4-8.
13. Carter TD, Mundo E, Parikh SV, Kennedy JL. Early age at onset as a risk factor for poor outcome of bipolar disorder. J Psychiatr Res. 2003;37(4): 297-303.

14. Lin PI, Mclnnis MG, Potash JB, et al. Clinical correlates and familial aggregation of age at onset in bipolar disorder. Am J Psychiatry. 2006;163(2): 240-246.

15. Leverich GS, Post RM, Keck PE Jr, et al. The poor prognosis of childhood-onset bipolar disorder. J Pediatr. 2007;150(5): 485490.

16. Post RM, Kowatch RA. The health care crisis of childhood-onset bipolar illness: some recommendations for its amelioration. J Clin Psychiatry. 2006;67(1): 115-125.

17. Youngstrom E, Van Meter A, Algorta GP. The bipolar spectrum: myth or reality? Curr Psychiatry Rep. 2010;12(6): 479-489.

18. Van Meter AR, Moreira AL, Youngstrom EA. Meta-analysis of epi`demiologic studies of pediatric bipolar disorder. J Clin Psychiatry. 2011;72(9): 1250-1256.

19. JM David, DS Christopher, LG Elizabeth, OT Dawn, AS Catherine, B Boris, AK Robert, PDB Melissa, AA David. Pharmacotherapy and Family-Focused Treatment for Adolescents With Bipolar I and II Disorders: A 2-Year Randomized Trial. Am J Psychiatry. 2014; 171(6): 658-667.

20. Perlis RH, Miyahara S, Marangell LB, Wisniewski SR, Ostacher M, DelBello MP, Bowden CL, Sachs GS, Nierenberg AA. STEP-BD Investigators: Long-term implications of early onset in bipolar disorder: data from the first 1000 participants in the Systematic Treatment Enhancement Program for Bipolar Disorder (STEPBD). Biol Psychiatry. 2004; 55: 875-881.

21. Merikangas $K R$, Jin $R$, He JP, Kessler RC, Lee $S$, Sampson NA, Viana MC, Andrade LH, Hu C, Karam EG, Ladea M, MedinaMora ME, Ono Y, Posada-Villa J, Sagar R, Wells JE, Zarkov Z. Prevalence and correlates of bipolar spectrum disorder in the World Mental Health Survey Initiative. Arch Gen Psychiatry. 2011; 68: 241-251.

22. Päären A, Bohman $H$, Lars von Knorring LV, Olsson $G$, Knorring ALV, Jonsson U. Early risk factors for adult bipolar disorder in adolescents with mood disorders: a 15-year follow-up of a community sample. Päären et al. BMC Psychiatry (2014) 14: 363

23. Wozniak J, Biederman J, Kiely K, Ablon JS, Faraone SV, Mundy E, Mennin D. Mania-like symptoms suggestive of childhood-onset bipolar disorder in clinically referred children. J Am Acad Child Adolesc Psychiatry 1995, 34(7): 867-876.

24. Egeland JA, Hostetter AM, Pauls DL, Sussex JN: Prodromal symptoms before onset of manic-depressive disorder suggested by first hospital admission histories. J Am Acad Child Adolesc Psychiatry 2000, 39(10): 1245-1252.

25. Geller B, Zimerman B, Williams M, Delbello MP, Frazier J, Beringer L: Phenomenology of prepubertal and early adolescent bipolar disorder: examples of elated mood, grandiose behaviors, decreased need for sleep, racing thoughts and hypersexuality. J Child Adolesc Psychopharmacol 2002, 12(1): 3-9. 
26. Fergus EL, Miller RB, Luckenbaugh DA, Leverich GS, Findling $R L$, Speer AM, Post RM: Is there progression from irritability/ dyscontrol to major depressive and manic symptoms? A retrospective community survey of parents of bipolar children. J Affect Disord 2003, 77(1): 71-78.

27. Egeland JA, Shaw JA, Endicott J, Pauls DL, Allen CR, Hostetter AM, Sussex JN: Prospective study of prodromal features for bipolarity in well. Amish children. J Am Acad Child Adolesc Psychiatry 2003, 42(7): 786-796.

28. Chang K, Steiner H, Dienes K, Adleman N, Ketter T: Bipolar offspring: a window into bipolar disorder evolution. Biol Psychiatry 2003,53(11): 945-951.

29. Duffy A: Does bipolar disorder exist in children? A selected review. Can J Psychiatry 2007, 52(7): 409-417.

30. Biederman J, Russell R, Soriano J, Wozniak J, Faraone SV: Clinical features of children with both ADHD and mania: does ascertainment source make a difference? J Affect Disord 1998, 51(2): 101-112

31. Kim-Cohen J, Caspi A, Moffitt TE, Harrington H, Milne BJ, Poulton R: Prior juvenile diagnoses in adults with mental disorder: developmental follow-back of a prospectivelongitudinal cohort. Arch Gen Psychiatry 2003, 60(7): 709-717.

32. Hirshfeld-Becker DR, Biederman J, Henin A, Faraone SV, Cayton GA, Rosenbaum JF: Laboratory-observed behavioral disinhibition in the young offspring of parents with bipolar disorder: a high-risk pilot study. Am J Psychiatry 2006, 163(2): 265-271.

33. Tijssen MJ, Van Os J, Wittchen HU, Lieb R, Beesdo K, Wichers M: Risk factors predicting onset and persistence of subthreshold expression of bipolar psychopathology among youth from the community. Acta Psychiatry Scand 2010, 122(3): 255-266.

34. Johnson JG, Cohen P, Brook JS. Associations between bipolar disorder and other psychiatric disorders during adolescence and early adulthood: a community-based longitudinal investigation. Am J Psychiatry 2000, 157(10): 1679-1681.

35. Wozniak J, Biederman J, Monuteaux MC, Richards J, Faraone SV: Parsing the comorbidity between bipolar disorder and anxiety disorders: a familial risk analysis. J Child Adolesc Psychopharmacol 2002, 12(2): 101-111.

36. Birmaher B, Kennah A, Brent D, Ehmann M, Bridge J, Axelson D: Is bipolar disorder specifically associated with panic disorder in youths? J ClinPsychiatry 2002, 63(5): 414-419.

37. Diler RS, Birmaher B, Brent DA, Axelson DA, Firinciogullari $S$, Chiapetta L, Bridge J. Phenomenology of panic disorder in youth. Depress Anxiety 2004, 20(1): 39-43.

38. Goldstein BI, Strober MA, Birmaher B, et al. Substance use disorders among adolescents with bipolar spectrum disorders. Bipolar Disorders. 2008; 10(4): 469-478.
39. Wilens TEMM, Kruesi MJP, Parcell T, Westerberg D, Schillinger M, Gignac M, Biederman J. Does conduct disorder mediate the development of substance use isorders in adolescents with bipolar disorder? A case-control family study. Journal of Clinical Psychiatry. 2009; 70(2): 259-265.

40. Wilens TE, Biederman J, Adamson J, et al. Association of bipolar and substance use disorders in parents of adolescents with bipolar disorder. Biological Psychiatry. Jul 15; 2007 62(2): 129-134.

41. Strakowski SM, DelBello MP, Fleck DE, et al. Effects of cooccurring cannabis use disorders on the course of bipolar disorder after a first hospitalization for mania. Archives of General Psychiatry. Jan; 2007 64(1): 57-64.

42. Strakowski SM, DelBello MP, Fleck DE, et al. Effects of cooccurring alcohol abuse on the course of bipolar disorder following a first hospitalization for mania. Archives of General Psychiatry. Aug; 2005 62(8): 851-858.

43. Nesvag R, Knudsen GP, Høye IJBA, Ystrom E, Sure'n P, Anne Reneflot, Stoltenberg C, Reichborn-Kjennerud T. Substance use disorders in schizophrenia, bipolar disorder and depressive illness: a registry-based study. Soc Psychiatry Psychiatr Epidemiol 2015.

44. Negrete JC (2003) Clinical aspects of substance abuse in persons with schizophrenia. Can J Psychiatry 48: 14-21

45. Margolese HC, Malchy L, Negrete JC, Tempier R, Gill K (2004) Drug and alcohol use among patients with schizophrenia and related psychoses: levels and consequences. Schizophr Res. 67: 157-166

46. Turkington A, Mulholland CC, Rushe TM, Anderson R, McCaul R, Barrett SL, Barr RS, Cooper SJ (2009) Impact of persistent substance misuse on 1-year outcome in first-episode psychosis. Br J Psychiatry 195: 242-248

47. Cantor-Graae E, Nordstro"m LG, Mcneil TF (2001) Substance abuse in schizophrenia: a review of the literature and a study of correlates in Sweden. Schizophr Res 48: 69-82

48. Opsal A, Clausen T, Kristensen O, Elvik I, Joa I, Larsen TK (2011) Involuntary hospitalization of first-episode psychosis with substance abuse during a 2-year follow-up. Acta Psychiatr Scand 124: 198-204

49. Kavanagh DJ, McGrath J, Saunders JB, Dore G, Clark D (2002) Substance misuse in patients with schizophrenia: epidemiology and management. Drugs 62: 743-755

50. Lagerberg TV, Andreassen OA, Ringen PA, Berg AO, Larsson S, Agartz I, Sundet K, Melle I (2010) Excessive substance use in bipolar disorder is associated with impaired functioning rather than clinical characteristics, a descriptive study. BMC Psychiatry 10: 9. doi: 10.1186/1471-244X-10-9.

51. Regier DA, Farmer ME, Rae DS, Locke BZ, Keith SJ, Judd LL, Goodwin FK (1990) Comorbidity of mental disorders with alcohol and other drug abuse. Results from the Epidemiological Catchment Area (ECA) Study. JAMA 264: 2511-2518. 
52. Kendler KS, Gallagher TJ, Abelson JM, Kessler RC (1996) Lifetime prevalence, demographic risk factors, and diagnostic validity of nonaffective psychosis as assessed in a US community sample. The National Comorbidity Survey. Arch Gen Psychiatry 53: 1022-1031

53. Grant BF, Stinson FS, Hasin DS, Dawson DA, Chou SP, Ruan WJ, Huang B (2005) Prevalence, correlates, and comorbidity of bipolar I disorder and axis I and II disorders: results from the National Epidemiologic Survey on alcohol and related conditions. J Clin Psychiatry 66: 1205-1215

54. Hasin DS, Goodwin RD, Stinson FS, Grant BF (2005) Epidemiology of major depressive disorder: results from the National Epidemiologic Survey on alcoholism and related conditions. Arch Gen Psychiatry 62: 1097-1106

55. Larsen TK, Melle I, Auestad B, Friis S, Haahr U, Johannessen JO, Opjordsmoen S, Rund BR, Simonsen E, Vaglum P, McGlashan TH (2006) Substance abuse in first-episode non-affective psychosis. Schizophr Res 88: 55-62

56. Nesva ${ }^{\circ} \mathrm{R}$, Lange $E H$, Faerden $A$, Barrett EA, Emilsson $B$, Ringen PA, Andreassen OA, Melle I, Agartz I (2010) The use of screening instruments for detecting alcohol and other drug use disorders in first-episode psychosis. Psychiatry Res 177: 228-234

57. Ringen PA, Melle I, Birkenaes AB, Engh JA, Faerden A, Jo'nsdo'ttir $H$, Nesva ${ }^{\circ}$ R, Vaskinn A, Friis S, Larsen F, Opjordsmoen S, Sundet K, Andreassen OA (2008) Illicit drug use in patients with psychotic disorders compared with that in the general population: a cross-sectional study. Acta Psychiatr Scand 117: 133-138

58. APA. Diagnostic and Statistical Manual of Mental Disorders. 4 th edition. Washington, DC: Author; 2000.

59. Axelson D, Birmaher B, Strober M, Gill MK, Valeri S, Chiappetta L, Ryan N, Leonard H, Hunt J, lyengar S, Bridge J, Keller M. Phenomenology of children and adolescents with bipolar spectrum disorders. Archives of general psychiatry. 2006; 63(10): 1139-1148.

60. Birmaher B. Longitudinal course of pediatric bipolar disorder. The American journal of psychiatry. 2007; 164(4): 537-539.

61. Carlson GA. Will the child with mania please stand up? British Journal of Psychiatry. 2011. 198(3): 171-172.

62. Findling RL, Youngstrom EA, Fristad MA, Birmaher B, Kowatch RA, Arnold LE, Frazier TW, Axelson D, Ryan N, Demeter CA, Gill MK, Fields B, Depew J, Kennedy SM, Marsh L, Rowles BM, Horwitz SM. Characteristics of children with elevated symptoms of mania: the Longitudinal Assessment of Manic Symptoms (LAMS) study. The Journal of clinical psychiatry. 2010; 71(12): 1664-1672.

63. Kowatch RA, Fristad M, Birmaher B, Wagner KD, Findling RL, Hellander M. Treatment guidelines for children and adolescents with bipolar disorder. Journal of the American Academy of Child and Adolescent Psychiatry. 2005a; 44(3): 213-235.
64. Youngstrom EA, Birmaher B, Findling RL. Pediatric bipolar disorder: validity, phenomenology, and recommendations for diagnosis. Bipolar Disorders. 2008; 10(1 Pt 2): 194-214.

65. Frazier TW, Youngstrom EA, Fristad MA, Demeter C, Birmaher B, Kowatch RA, Arnold LA, Axelson D, Gill MK, Horwitz SM, Findling RL. Improving Clinical Prediction of Bipolar Spectrum Disorders in Youth. J Clin Med. 2014 ; 3(1): 218-232

66. Kraemer, HC. Evaluating Medical Tests: Objective and Quantitative Guidelines. Sage Publications; Newbury Park, CA, USA: 1992

67. Peruzzolo TL, Tramontina S, Rohde LA, Zeni CP. Pharmacotherapy of bipolar disorder in children and adolescents: an update. Revista Brasileira de Psiquiatria. 2013;35: 393-405

68. Chang KD. The use of atypical antipsychotics in pediatric bipolar disorder. J Clin Psychiatry. 2008;69 Suppl 4: 4-8.

69. Findling RL, Nyilas M, Forbes RA, McQuade RD, Jin N, Iwamoto T,et al. Acute treatment of pediatric bipolar I disorder, manic or mixed episode, with aripiprazole: a randomized, double-blind, placebocontrolled study. J Clin Psychiatry. 2009;70: 1441-51.

70. Mankoski R, Zhao J, Carson WH, Mathew SJ, Forbes RA. Young mania rating scale line item analysis in pediatric subjects with bipolar I disor $\neg$ der treated with aripiprazole in a short-term, double-blind, randomized study. J Child Adolesc Psychopharmacol. 2011;21(4): 359-364.

71. Doey T. Aripiprazole in pediatric psychosis and bipolar disorder: a clinical review. J Affect Disord. 2012;138 Suppl: S15-S21.

72. Picardi A, Gaetano P. Psychotherapy of Mood Disorders. Clinical Practice \& Epidemiology in Mental Health, 2014, 10, 140-158

73. Scott J, Colom F, Vieta E. A meta-analysis of relapse rates with adjunctive psychological therapies compared to usual psychiatric treatment for bipolar disorders. Int J Neuropsychopharmacol 2007; 10: 123-9

74. Hollon SD, Ponniah K. A review of empirically supported psychological therapies for mood disorders in adults. Depress Anxiety 2010; 27: 891-932.

75. Narvaez JC, Zeni CP, Coelho RP, Wagner F, Pheula GF, Ketzer CR, Trentini CM, Tramontina S, Rohde LA. Does comorbid bipolar disorder increase neuropsychological impairment in children and adolescents with ADHD? Revista Brasileira de Psiquiatria. 2014;36: 53-59

76. Mais G, Pisano S, Pfanner C, Milone A, Manfredi A. Quetiapine Monotherapy in Adolescents with Bipolar Disorder Comorbid with Conduct Disorder. Journal Of Child And Adolescent Psychopharmacology. 2013; 23: 8: 568-571

77. Masi G, Perugi G, Toni C, Millepiedi S, Mucci M, Bertini N, Akiskal HS: Predictors of treatment non-response on bipolar children and adolescents with manic or mixed episodes. J Child Adolesc Psychopharmacol 14: 403-412, 2004.

78. Masi G, Milone AR, Manfredi A, Pari C, Paziente A, Millepiedi S: Comorbidity of conduct disorder and bipolar disorder in referred children and adolescents. J Child Adolesc Psychopharmacol 18: 271-279, 2008. 
79. Latalova K, Kamaradova D \& Prasko J: SUICIDE IN BIPOLAR DISORDER: A REVIEW. Psychiatria Danubina, 2014; Vol. 26, No. 2, pp 108-114

80. Crump C, Sundquist K, Winkleby MA \& Sundquist J: Comorbidities and mortality in bipolar disorder: a Swedish national cohort study. AMA Psychiatry 2013; 70: 931-939.

81. Hoang U, Goldacre MJ \& Stewart R: Avoidable mortality in people with schizophrenia or bipolar disorder in England. Acta Psychiatr Scand 2013; 127: 195-201.

82. Oquendo MA, Currier D, Liu SM, Hasin DS, Grant BF \& Blanco C: Increased risk for suicidal behavior in comorbid bipolar disorder and alcohol use disorders: results from the National Epidemiologic Survey on Alcohol and Related Conditions (NESARC). Clin Psychiatry 2010;71: 902-909.

83. Malhi GS, Tanious M, Das P \& Berk M: The science and practice of lithium therapy. Australian and New Zealand Journal of Psychiatry 2012; 46: 192-211.

84. Wasserman D, Rihmer Z, Rujescu D, Sarchiapone M, Sokolowski M, Titelman D, Zalsman G, Zemishlany Z \&Carli V: The European Psychiatric Association (EPA)guidance on suicide treatment and prevention. Eur Psychiatry 2012; 27: 129-141.

\section{Comment on this article:}

\section{$4[8$ in $8+\mathbf{S} P$}

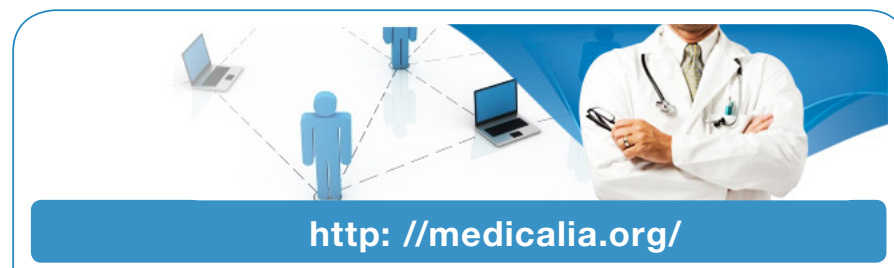

Where Doctors exchange clinical experiences, review their cases and share clinical knowledge. You can also access lots of medical publications for free. Join Now!

\section{Publish with iMedPub}

http: //www.imed.pub

International Archives of Medicine is an open access journal publishing articles encompassing all aspects of medical science and clinical practice. IAM is considered a megajournal with independent sections on all areas of medicine. IAM is a really international journal with authors and board members from all around the world. The journal is widely indexed and classified Q1 in category Medicine. 